\title{
Mitigating effect of salicylic acid in the anatomy of the leaf of Zea mays L. lluteño ecotype from the Lluta Valley (Arica-Chile) under $\mathrm{NaCl}$ stress
}

\author{
Efecto mitigador del ácido salicílico en la anatomía de la hoja de \\ Zea mays L. lluteño ecotipo del Valle de Lluta (Arica-Chile) en estrés $\mathrm{NaCl}$ \\ Henry J. Cárcamo, Richard M. Bustos ${ }^{1}$, Felipe E. Fernández, Elizabeth I. Bastías ${ }^{1 *}$
}

\begin{abstract}
It is known that exogenous salicylic acid (SA) plays a role in the response of plants to salt and osmotic stresses. In recent years, SA has been shown to increase the concentrations of organic solutes for osmoregulation in plants subjected to salt stress. Therefore an experiment was conducted to investigate the impact of exogenous SA on the tissue morphology of lluteño maize. The treatment consisted of salt and SA $(0.1 \mathrm{mM})$. Salt stress negatively affected leaf anatomy by showed a positive effect of SA on the composition of structures such as xylem vessels, Kranz anatomy, mesophyll cells, epidermal tissues, leaf blades and chloroplast development. It also increased the number of stomata per unit area. Finally, the presence of salicylic acid in saline conditions has beneficial effects on the morphology of lluteño maize, likely contributing to the tolerance to salinity.
\end{abstract}

Key words: Zea mays L. amilacea, salinity, anatomy, salicylic acid.

\section{RESUMEN}

Se sabe que la aplicación del ácido exógeno salicílico (SA) desempeña un papel en la respuesta de las plantas a la salinidad y al estrés osmótico. En años recientes se ha demostrado que el SA aumenta las concentraciones de solutos orgánicos para la osmorregulación en las plantas sometidas a estrés salino. Por lo tanto, se realizó un experimento para investigar el impacto de factores exógenos como el SA en la morfología de los tejidos de maíz lluteño. El tratamiento consistió en NaCl y SA (0,1 mM). El estrés salino afecta negativamente la anatomía de la hoja, pero mostró un efecto positivo de SA en la composición de estructuras tales como los vasos del xilema, la anatomía Kranz, células mesofílicas, tejidos epidérmicos, láminas foliares y el desarrollo del cloroplasto. También aumentó el número de estomas por unidad de área. Finalmente, la presencia de ácido salicílico en condiciones salinas tiene efectos favorables sobre la morfología de maíz. lluteño, probablemente contribuyendo a la tolerancia a la salinidad.

Palabras clave: Zea mays L. amilácea, salinidad, anatomía, acido salicílico.

\section{Introduction}

Plants are subjected to various types of stress, most of which are related to water availability, such as salinity, drought, high and low temperatures. Among these salinity is the most threatening abiotic stress for plants; which may affect negatively productivity and quality. Up to $7 \%$ of the total land surface of the planet is saline (Munns, 2002). This is a growing problem due to use of poor quality water with high concentrations of sodium (Cardona et al., 2004; Horie \& Schroeder, 2004; Chinnusami et al., 2005). Water and soil salinity, mainly in semi arid regions, may affect agricultural activity, limiting the types of crops and their yields and generating marginal lands. A saline soil has a permanent problem of hyperosmotic stress, hypoxia and nutritional imbalance (Maggio et al., 2004).

The Lluta valley, in Northern Chile, is a typical case of high salinity and also high concentrations of boron (B) in soil and irrigation water (MartínezBallasta et al., 2008). The main crop in this valley is a local cultivar called lluteño maize; this crop deserves special attention because of its high tolerance to salinity stress and excess of $\mathrm{B}$ in irrigation water, and whose habitat is not known other kind of corn (Bastías et al., 2004). It has been reported that saline stress causes alterations in the structure

\footnotetext{
1 Departamento de Producción Agrícola, Facultad de Ciencias Agronómicas, Universidad de Tarapacá, Casilla 6-D, Arica-Chile.

* Autor por Correspondencia: ebastias@uta.cl
} 
and function of plant cells ( Hernández et al., 2001; Hernández and Almanza, 2002). These structural changes caused by salinity occur at several levels of organization (Olmedilla et al., 2012). At level of the whole plant, the anatomical-morphological changes that allow plants to resist salt effects are mainly oriented to maintain water use efficiency and balance carbon gain in plant tolerance to salts.

There are few anatomical studies on maize in saline conditions, and even fewer in lluteño maize, thus aim of this study was to analyze the alterations in the tissue organization in leaves of Zea mays L. cv lluteño as a consequence of stress with $\mathrm{NaCl}$ $(100 \mathrm{mM})$ in the presence and absence of salicylic acid $(0.1 \mathrm{mM})$.

\section{Materials and Methods}

The experiment was performed with plants of Zea mays L., cv lluteño in a greenhouse with natural light, mean maximum temperature $27.3^{\circ} \mathrm{C}$, mean minimum $11.4^{\circ} \mathrm{C}$, PAR $359.8 \mu \mathrm{mol} / \mathrm{m}^{2} \mathrm{~s}^{-1}$ and relative humidity $50 \%-80 \%$ (day-night). Plants were established in $15 \mathrm{~L}$ pots with a perlite substrate. Three seeds were planted in each pot. After 10 days, one of the three seedlings of each pot was selected to obtain plants with a uniform size for all the experimental groups; the other two were removed from the pot. During the first 28 days plants were irrigated with 100\% Hoagland's solution, pH 6-7 (Hoagland and Arnon, 1950). The plants were watered every two days with one liter of Hoagland's solution per pot when the substrate reached a humidity of $30 \%$ of the field capacity (FC) (Fuentes, 2003). To avoid the accumulation of nutrients and salts in the substrate, every third irrigation the substrate was washed with distilled water until the electrical conductivity of the substrate was less than that of the Hoagland solution. After 28 days the experimental treatments with $\mathrm{NaCl}, \mathrm{NO}_{3}{ }^{-}$and $\mathrm{SA}$ began. All these chemical compounds were added to the Hoagland medium (Gunes et al., 2007). Treatments are indicated in Table 1; there were 9 treatments with 5 repetitions using 5 plants per treatment. Treatments were continued for 58 days; measurements began after 30 days of treatment.

\section{Selection of samples and processing}

Segments of the seventh leaf of lluteño maize were collected and immediately cut into $5 \mathrm{~mm}^{2}$ pieces and fixed in formaldehyde; glacial acetic acid and 70\% ethanol (FAA 70) (5:5:90) for $48 \mathrm{~h}$. Subsequently, samples were post-fixed with phosphate buffer ( $\mathrm{pH}$ 7.4). They were dehydrated in an ascending series of alcohol (70\%-80\%-90\%-absolute I and absolute II). This was followed by infiltration with xylol I and xylol II overnight. Tissues were embedded in paraffin.

Finally, formed blocks of paraffin of $2 \mathrm{~cm}^{3}$ were cut with a rotary microtome (Reichter-Jung, mod. Rotocut, Heidelberg, Germany). For light microscopy, semi-thin sections $(7 \mu \mathrm{m})$ were fixed in a 2\% albumin solution (Bastías, 2005 y García, 2007). The samples were stained with safranin and fast-green and examined with a photo-microscope (Photo-microscope II, Carl Zeiss, Oberkochen, Alemania). Photographs were taken of at least ten random sites in three different sections and representative pictures are presented for the average measure were taken with the quantitative anatomical data image analysis program Motic Images Plus 2,0 . Stomata of leaves were observed with image analysis program an imprint of colourless collusions and examined with a photo-microscope. Photographs were taken of 2 random sites in three different sections. Quantitative data were recorded using the image analysis program Motic Images Plus 2.0 in

Table 1. Experimental treatments.

\begin{tabular}{cc}
\hline Treatment group & Treatments \\
\hline T1 & Control (Hoagland's solution only) \\
T2 & Control (Hoagland's solution only) $+100 \mathrm{mM} \mathrm{NaCl}(\mathrm{HS} 100)$ \\
T3 & HS100 $+6 \mathrm{mM} \mathrm{NO}-$ \\
T4 & HS $100+0.1 \mathrm{mM} \mathrm{SA}$ \\
T5 & HS100 $+0.5 \mathrm{mM} \mathrm{SA}$ \\
T6 & HS100 $+1.0 \mathrm{mM} \mathrm{SA}-$ \\
\hline
\end{tabular}


the leaf. The density of stomata in a specific area $\left(1 \mathrm{~mm}^{2}\right)$ was estimated. For the statistical analysis of the results, were applied test for mean comparison at 0.05 significance, using the SPSS program according to Duncan's multiple range test.

\section{Results}

A typical Kranz-type anatomy is present in all C4 plants; Zea mays L. cv lluteño is one of this type (Figure 1A). It presents adaxial and abaxial epidermis (AdE and AbE, respectively); both epidermises are monostratified and their cells are limited towards the outside by a thick and smooth cell wall. The two chlorenchyma cell types consisted of mesophyll (MC) and bundle sheath cells (BSC). The MC is oriented radially around the BSC; one parenchyma BSC layer surrounds the veins. Chloroplasts are present in the MC and BSC. The chloroplast in the BSC shows a centrifugal position. The application of the treatment with excess salt caused some alteration in the organization of foliar tissue. The differences were not evident in the treatments with SA (Figures 1A and 1C).

Under conditions of salinity significant changes were observed in the abaxial or lower epidermis $(\mathrm{AbE})$ and adaxial or upper epidermis (AdE), with irregular, deformed and compressed cells (Figure 1B). There was a statistically significant decrease of $36 \%$ in the epidermal thickness in comparison with control plants, however, the treatment with SA was statistically similar to control plants (Figure 2).

The stomata were found on both sides of the leaves. The stoma density was significantly greater in plants growing in presence of $\mathrm{NaCl}$ (Figure 3), possibly due to the leaf area of plants growing in the presence of $\mathrm{NaCl}$ being smaller than the control plants. The leaves of plants grown in presence of SA were similar to control plants in the number of stomata per specific area, thus suggesting the action of SA in mitigating salinity conditions (Figure 3 ).

Leaf thickness $(\mathrm{Lt})$ is the distance between the adaxial and abaxial surfaces of the leaf. It was observed that Lt diminished significantly in presence of $\mathrm{NaCl}$ (Figure 4B); this decrease was approximately $32 \%$ in comparison to controls (Figure 4A). This behavior could be observed by the decrease in the thickness of the MC portion in the presence of $\mathrm{NaCl}$. However, with the addition of SA Lt remained unchanged (Figure 4C); this treatment was statistically equal to the control (Figure 5).

The presence of $\mathrm{NaCl}$ showed evident structural alterations in mesophyll cell thickness (MCt), decreasing significantly (Figure 6). Figure 6B shows that the $\mathrm{MC}$ portion presented alterations in conformation and the intercellular spaces were diminished by $30 \%$, probably due to the compaction of the tissues under salinity (Figure 6B). However, with SA application in salinity conditions (Figure 6C), the MCt portions were similar to the control plants (Figure 7).

The distance between two adjacent vascular bundles $(\mathrm{dVB})$, showed significant variation in the presence of $\mathrm{NaCl}$ compared to control plants (Figures 8A and 8B), decreasing the distance by approximately $31 \%$, possibly due to the decrease of the portion of MC and BSC. The plants treated with SA (Figure 8C) than also decreased this character by less plant treated with $\mathrm{NaCl}$ not reach the values of control plant (Figure 9).

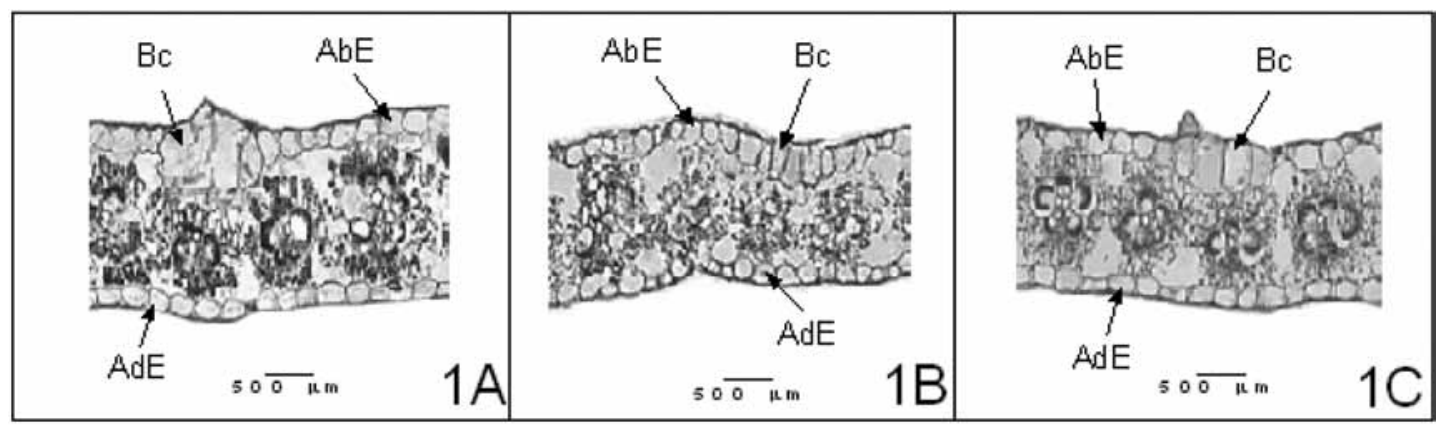

Figure 1. Light micrographs of the cross sections of leaves in plant of Zea mays L. amylacea. A: Control plant, treated in absence of $\mathrm{NaCl}(0 \mathrm{mM})$; B: plant treated with $\mathrm{NaCl}(100 \mathrm{mM})$; C: plant in saline conditions supplemented with SA $(0.1 \mathrm{mM})$. Bars represent $500 \mu \mathrm{m}$. Labels: AbE, abaxial epidermis; AdE, adaxial epidermis; Bc, buliform cell. 


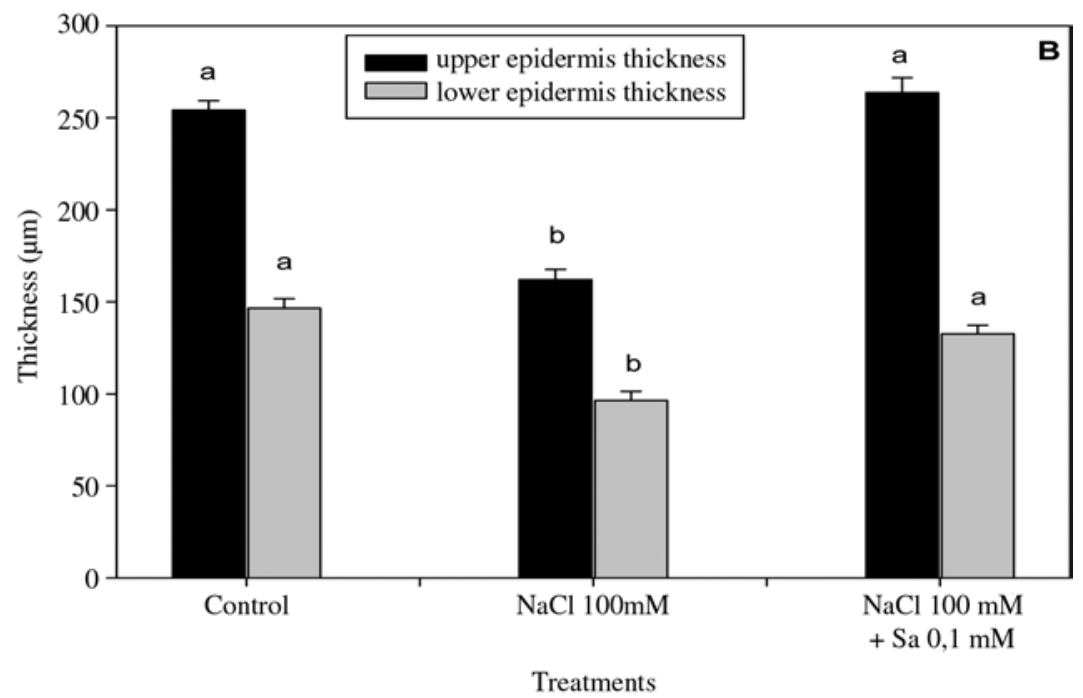

Figure 2. Adaxial epidermis (AdE) and Abaxial epidermis (AbE) thickness, in plants grown in the following treatments with $\mathrm{NaCl}$ (control, $0 \mathrm{mM}$ and $100 \mathrm{mM}$ ) and salicylic acid $(0.1 \mathrm{mM})$. Values represent the mean of ten samples \pm SE. Bars with the same letter are not significantly different according to LSD at a level of $\mathrm{P}<0.05$.

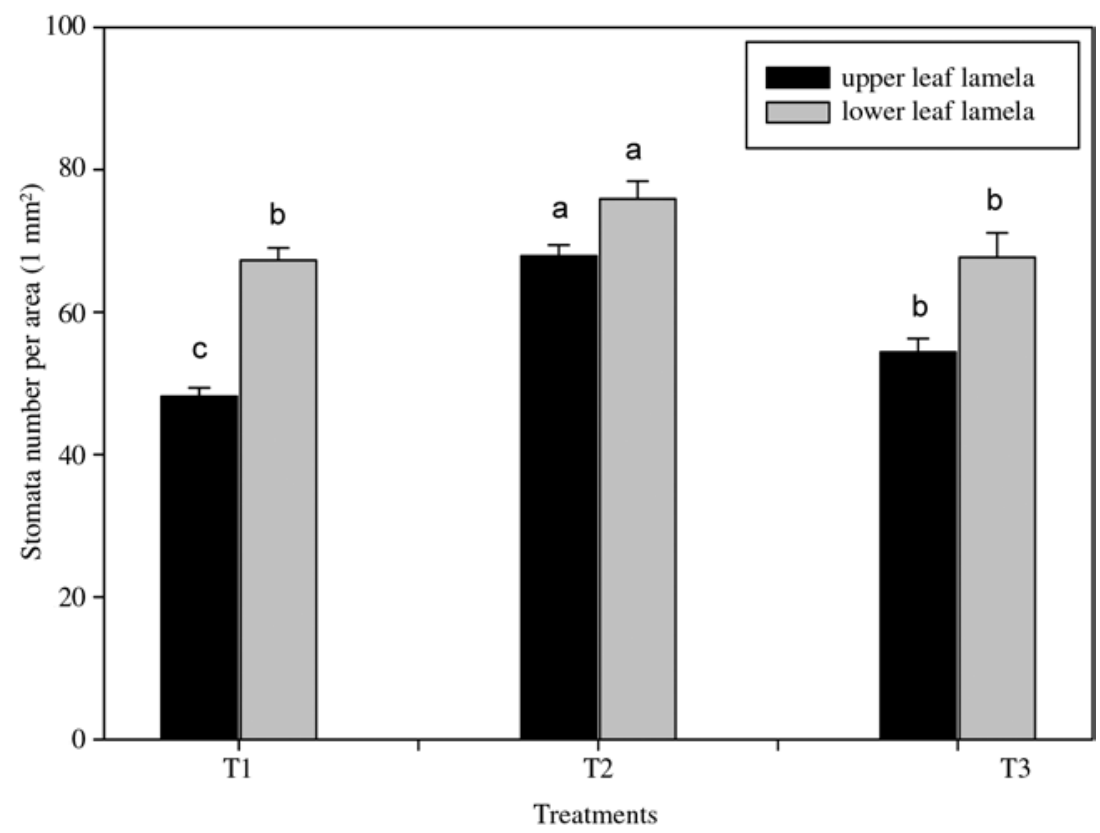

Figure 3. Stomata number per specific area $\left(1 \mu \mathrm{m}^{2}\right)$ in plants grown in the following treatments with $\mathrm{NaCl}$ (control, $0 \mathrm{mM}$ and $100 \mathrm{mM})$ and $\mathrm{SA}(0.1 \mathrm{mM})$. Values represent the mean of ten samples \pm SE. Bars with the same letter are not significantly different according to LSD at a level of $\mathrm{P}<0.05$.

In plants grown with $\mathrm{NaCl}$ the alterations in the spatial location of chloroplasts was evident, losing the centrifugal position in BSC (Figure 10B) and being scattered throughout the cytoplasm of the cell. With SA were not different at the position of chloroplasts the central plant, they were located in centrifugal position (Figure 10C). The same result was observed for chloroplasts of $\mathrm{MC}$, in the presence of $\mathrm{NaCl}$ there was a significant variation in quantity among plants controls and a notorious disorder of the chloroplast (Figure 10B) compared to controls (Figure 10A). 


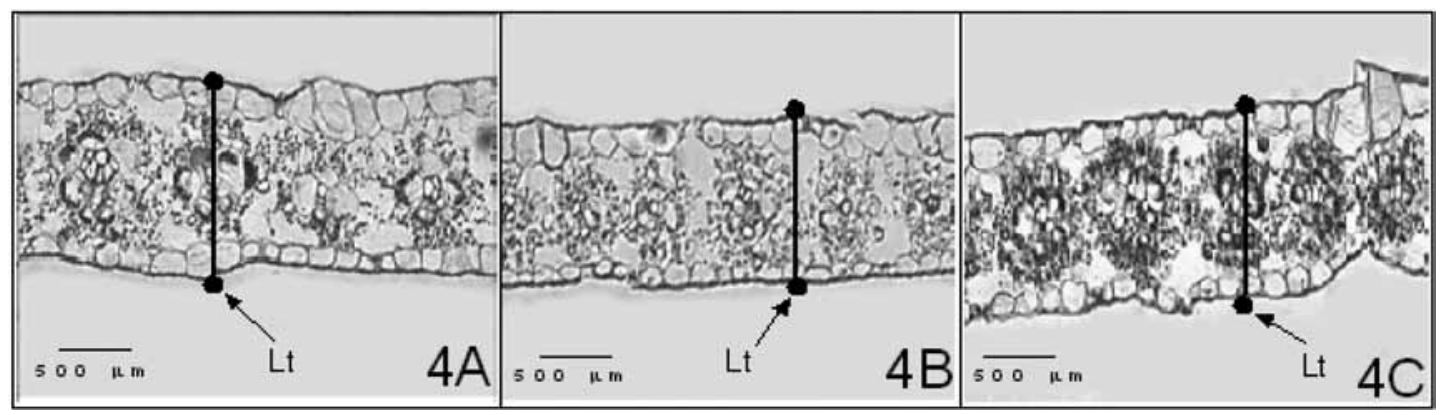

Figure 4. Light micrographs of the cross sections of leaves in plant of Zea mays L. amylacea. A: Control plant, treated in absence of $\mathrm{NaCl}(0 \mathrm{mM})$; B: plant treated with $\mathrm{NaCl}(100 \mathrm{mM})$; C: plant in saline conditions supplemented with SA $(0.1 \mathrm{mM})$. Bars represent $500 \mu \mathrm{m}$. Label: Lt, leaf thickness.

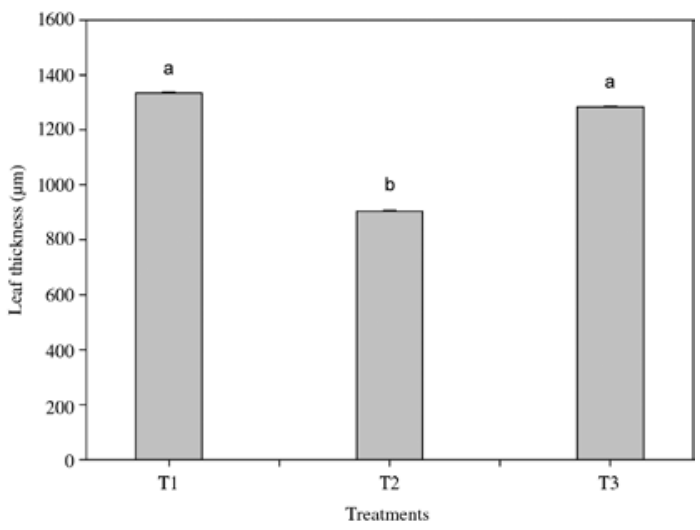

Figure 5. Leaf thickness $(\mathrm{Lt})$, in plants grown in the following treatments with $\mathrm{NaCl}$ (control, $0 \mathrm{mM}$ and $100 \mathrm{mM}$ ) and $\mathrm{SA}(0.1$ $\mathrm{mM})$. Values represent the mean of ten samples \pm SE. Bars with the same letter are not significantly different according to LSD at a level of $\mathrm{P}<0.05$.
The Kranz anatomy (KAa) and the vascular bundle (VB) area in plants grown with SA and controls did not show statistical differences (Figure 11). The application of $\mathrm{NaCl}$ to the medium (Figure 10B) caused alterations in the area of KAa; a statistically significant reduction in the area was observed, possibly due to a compaction of MC and a reduction of intercellular spaces (Figure 11).

\section{Discussion}

The results showed an important effect of SA in alleviating the alterations in the leaf tissue organization after 40 days in the presence of $\mathrm{NaCl}(100$ $\mathrm{mM}$ ) in the seedlings of lluteño maize; the anatomy of the foliar tissue was markedly affected, showing morphological changes compared to control plants.

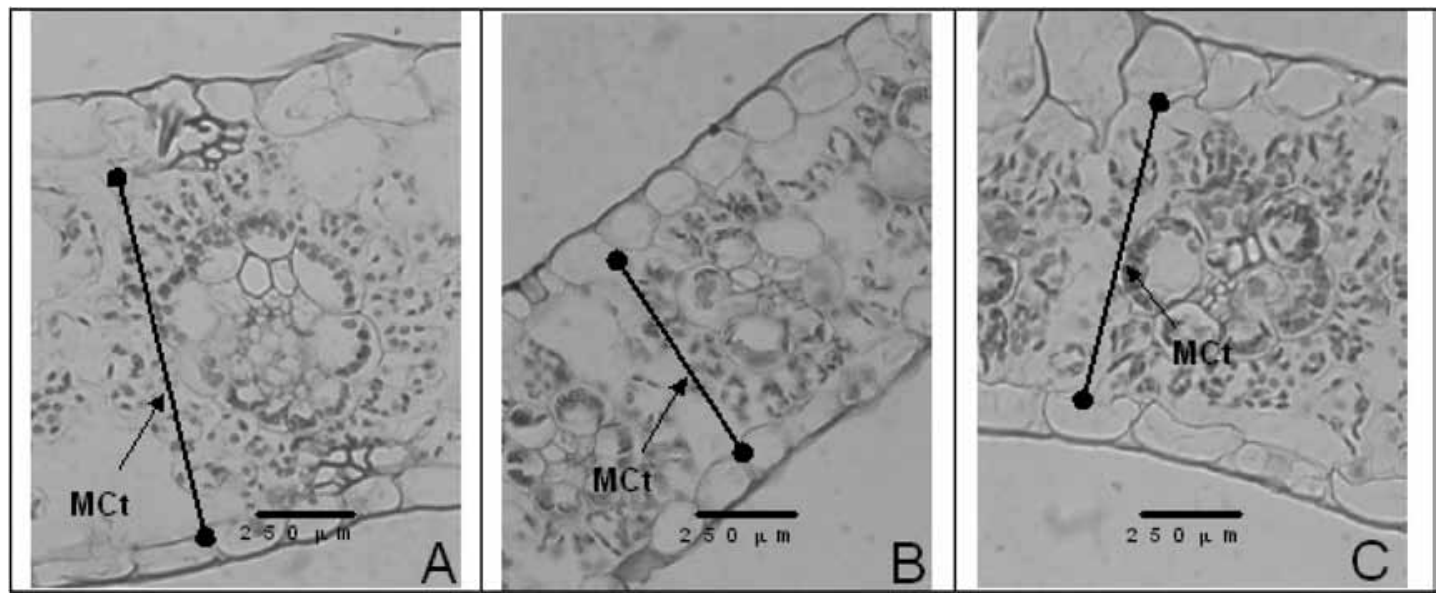

Figure 6. Light micrographs of the cross sections of leaves in plant of Zea mays L. amylacea. A: Control plant, treated in absence of $\mathrm{NaCl}(0 \mathrm{mM})$; B: plant treated with $\mathrm{NaCl}(100 \mathrm{mM})$; C: plant in saline conditions supplemented with SA $(0.1 \mathrm{mM})$. Bars represent $250 \mu \mathrm{m}$. Label: MCt, Mesophyll cell thickness. 


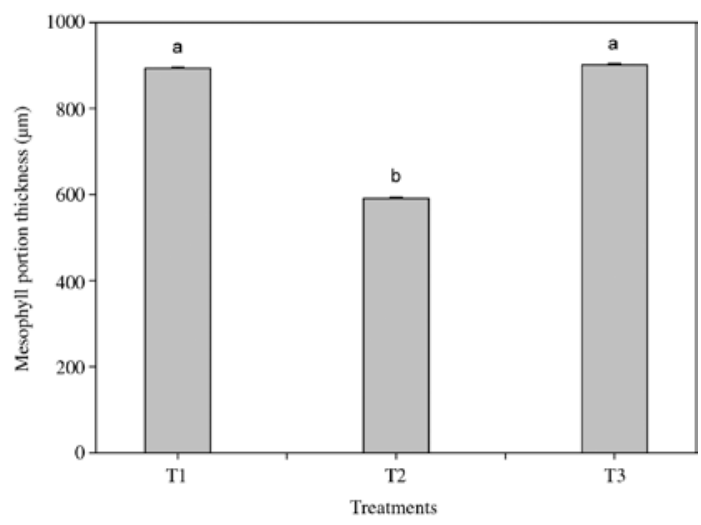

Figure 7. Mesophyll cells thickness (MCt), in plants grown in the following treatments with $\mathrm{NaCl}$ (control, $0 \mathrm{mM}$ and $100 \mathrm{mM}$ ) and SA $(0.1 \mathrm{mM})$. Values represent the mean of ten samples \pm SE. Bars with the same letter are not significantly different according to LSD at a level of $\mathrm{P}<0.05$. same behavior in plants treated with $\mathrm{NaCl}$ in the mangrove $B$. Parviflora. This coincides with Bastías (2005), who treated this ecotype with $430 \mathrm{mM}$ of $\mathrm{NaCl}$ for 20 days, finding a reduction of the leaf thickness as well as a decrease of the MC portion in number and size, indicating a limitation of cell growth, since division and cell expansion would be more affected as a result of osmotic and/or water stress in the MC cells (Bastías, 2005). Also in two tomato cultivars, spinach and wheat plants under saline stress $(75-120 \mathrm{mM} \mathrm{NaCl})$ a decrease in leaf thickness was observed (Hu et al., 2005). A suppression of cell enlargement is implicit in the older osmotic interpretation of salinity (Borsani et al., 2001) which attributed the growth suppression to an osmotic inhibition of water absorption by the plant. There is abundant experimental evidence that

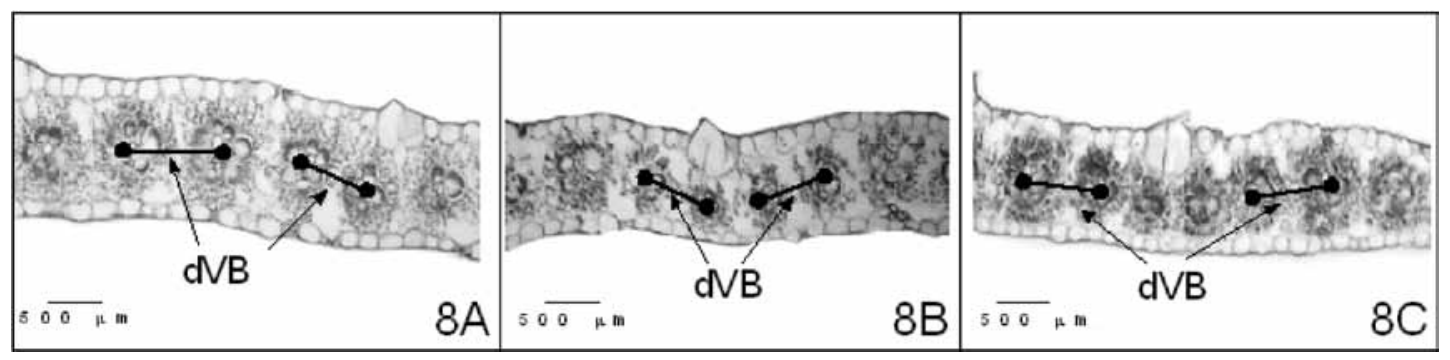

Figure 8. Light micrographs of the cross sections of leaves in plant of Zea mays L. amylacea. A: Control plant, treated in absence of $\mathrm{NaCl}(0 \mathrm{mM})$; B: plant treated with $\mathrm{NaCl}(100 \mathrm{mM})$; C: plant in saline conditions supplemented with SA $(0.1 \mathrm{mM})$. Bars represent $500 \mu \mathrm{m}$. Label: dVB: distance between vascular bundless.

This behavior confirms the reports that saline stress causes alterations in the structure and function of plant cells (Hernández et al., 2001; Hernández and Almanza, 2002). The anatomical-morphological changes that allow plants to resist salt effects are mainly oriented to maintain the efficiency of water use and balance carbon gain in plant tolerance to salt. The effect of salt stress on maize leaf growth and shoot development is similar to its effect on sorghum and lettuce. In the three species salinity decreases rates of leaf elongation and maximum leaf length.

The presence of $\mathrm{NaCl}(100 \mathrm{mM})$ caused a significant decrease in the thickness of the epidermis, with irregular cells and deformed buliform cells in $\mathrm{AdE}$ and $\mathrm{AbE}$ and decreased leaf thickness in lluteño maize. Parida et al. (2004) described the

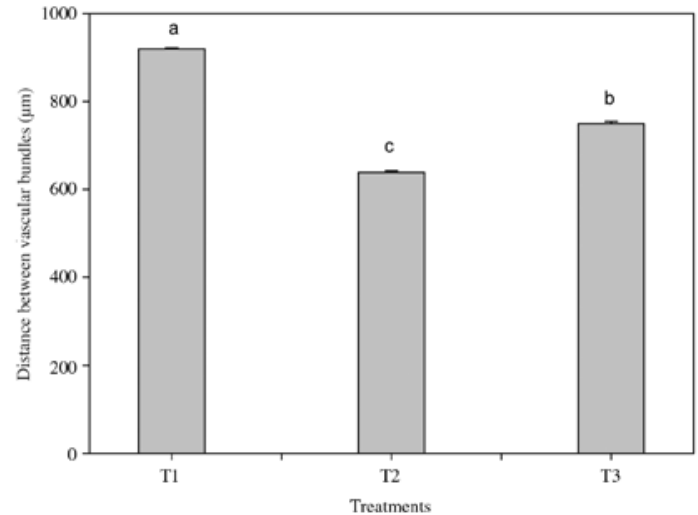

Figure 9. Distance between vascular bundles (dVB), in plants grown in the following treatments with $\mathrm{NaCl}$ (control, $0 \mathrm{mM}$ and $100 \mathrm{mM})$ and SA $(0.1 \mathrm{mM})$. Values represent the mean of ten samples \pm SE. Bars with the same letter are not significantly different according to LSD at a level of $\mathrm{P}<0.05$. 

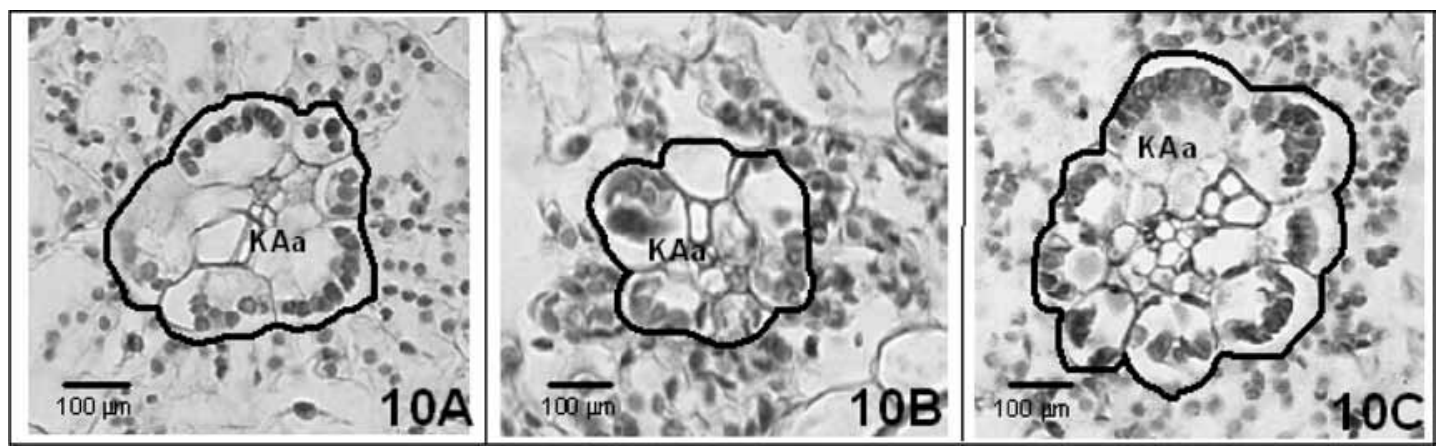

Figure 10. Light micrographs of the cross sections of leaves in plant of Zea mays L. amylacea. A: Control plant, treated in absence of $\mathrm{NaCl}(0 \mathrm{mM})$; B: plant treated with $\mathrm{NaCl}(100 \mathrm{mM})$; C: plant in saline conditions supplemented with SA $(0.1 \mathrm{mM})$. Bars represent X100 $\mu$ m. Label: KAa, Kranz anatomy area.

the salt effect is basically osmotic. Under saline conditions, growth may be limited also by metabolic limitations which might be caused by ion toxicity due to the accumulation of $\mathrm{Na}^{+}$and $\mathrm{Cl}^{-}$used for osmotic adjustment. Nevertheless, our data show that in plants treated with $\mathrm{NaCl}$ plus $\mathrm{SA}$, the $\mathrm{AdE}$ and $\mathrm{AbE}$, leaf and mesophyll portion thickness did not show changes in comparison with control plants. The epidermal cells were regular and turgescent, with large buliform cells similar to control plants. With respect to leaf thickness, it is known that the reduced leaf area due to salinity cannot be caused by cell division, but rather by cell enlargement. reported that aqueous solutions of SA applied as a spray to leaves of soybean significantly increased the growth of leaves and roots either in greenhouse or field conditions. In our study, the results obtained are consistent with the above; we observed that SA

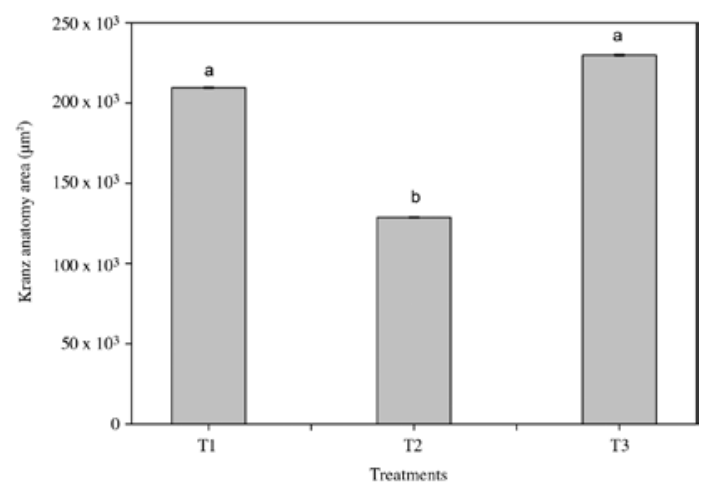

Figure 11. Area of Kranz anatomy (KAa), in plants grown in the following treatments with $\mathrm{NaCl}$ (control, $0 \mathrm{mM}$ and $100 \mathrm{mM}$ ) and SA $(0.1 \mathrm{mM})$. Values represent the mean of ten samples \pm SE. Bars with the same letter are not significantly different according to LSD at a level of $\mathrm{P}<0.05$. may stimulate or attenuate the effect of salinity on the anatomical parameters of leaves (Borsani et al., 2001).

The change in transpiration caused by salinity should be related to the reduced stomatal conductance and the lower stoma density of leaves under saline conditions, as indicated by the close correlation found between these parameters (Romero-Aranda et al., 2000). In this ecotype, the stoma density in a specific area was significantly increased (30\%) on both faces of the epidermis. A similar behavior has been reported for other species such as beans and Hibiscus cannabinus in saline conditions. By contrast, Romero-Aranda et al. (2000) found that reduction of foliar stoma density in plants of salt-treated tomato $(70 \mathrm{mM} \mathrm{NaCl})$ compared to non-treated plants was about $45 \%$. However, plants treated with SA $(0.1 \mathrm{mM})$ showed a similar stomata number per specific area to control plants on both sides of leaf (Figure 3).

Several studies have indicated that chloroplast ultrastructure in both halophytes and glucophytes is considerably affected by salinity. Plants treated with $\mathrm{NaCl}(100 \mathrm{mM})$ (Figure 10) showed a disorganization of the chloroplasts in BSC and MC (Figure 10B) in BSC; the chloroplast lost its centrifugal position. In MC, the chloroplasts were disordered and showed a small decrease in number (Figure 10B). These results are consistent with those mentioned by Bastías (2005), who saw some disorganization in the chloroplasts in the BSC of lluteño maize, which lost their perpendicular disposition to the cell wall and became parallel to it. In addition, in rice, wheat and Ipomea batata Lam., similar behavior of the chloroplasts in the presence of salinity was also reported (Yamane et al., 2004). In plants treated 
with SA $(0.1 \mathrm{mM})$, the chloroplast maintained its centrifugal organization in BSC, and in $\mathrm{MC}$ the chloroplasts had similar size and appearance to control plants (Figure 10C). This result suggests that SA serves to give better protection to the plant of lluteño maize during salt stress.

A growing amount of evidence suggests that $\mathrm{SA}$ is an endogenous signal for the activation of certain plant defense responses, establishment of enhanced disease resistance and abiotic stress problems interfering with membrane ion transport (Omoto et al., 2012).

Toxic accumulation of $\mathrm{Na}^{+}$and $\mathrm{Cl}^{-}$in the leaves has also been correlated with stomatal closure and with nonstomatal factors such as reduction in total chlorophyll content, both of which limit the amount of photoassimilate production (Omoto et al., 2012). However, the maintenance of the organization of chloroplasts under salinity in the presence of SA $(0.1 \mathrm{mM})$ could maintain the photosynthetic capacity of lluteño maize (Figure 10C).

SA has an important competition with ions such as $\mathrm{Na}^{+}$at the membrane transport level; this coincides with Gunes (2005), who indicated that positive effects of SA on ion uptake and inhibitory effects on $\mathrm{Na}^{+}$and $\mathrm{Cl}^{-}$uptake should also be responsible for managing salinity in maize plants.
This could explain the similarity in this study of the plants treated with SA and control plants compared to plants treated with $\mathrm{NaCl}(100 \mathrm{mM})$. The SA could generate a high level of ionic competition with $\mathrm{Na}^{+}$ and $\mathrm{Cl}^{-}$, thus avoiding the ionic phytotoxicity in plant tissues, allowing an effective development at the cell and tissue levels.

It is important to emphasize that changes detected at the cellular level in this study are much smaller in relation to intensity of applied stresses, with only $100 \mathrm{mM}$ of $\mathrm{NaCl}$ and described in bibliography for different maize cultivars and other species of crops in saline conditions. The results of this study show that the presence of $\mathrm{NaCl}(100 \mathrm{mM})$ caused changes in the anatomy of the leaf structure in maize cv lluteño. This change could affect the growth of the plant. Nevertheless, SA had a significant protective effect on cellular structures in lluteño maize under saline conditions, maintaining the values of the different anatomical parameters similar to those obtained in control plants (Omoto et al., 2012).

\section{Agradecimientos}

This study was financed by the Convenio de Desempeño UTA-MECESUP 2 (Arica-Chile) and Proyecto CONICYT MEC FOLIO: 80100015.

\section{Literature Cited}

Bastías, E.; González-Moro, M.B.; González-Murúa, C. 2004 Zea mays L. amylacea from the Lluta Valley (AricaChile) tolerates salinity stress when high levels of boron are available. Plant and Soil 267: 73-84.

Bastías, E.

2005 Interacción del boro en la tolerancia a la salinidad de Zea mays L. amylacea originario del Valle de Lluta (AricaChile). Tesis de Doctorado. Universidad del País Vasco. España. 314 pp.

Bernstein, N.; Silk, W.K.; Lauchli, A. 1993 Spatial and temporal aspects of sorghum leaf growth under conditions of $\mathrm{NaCl}$ stress. Planta 191: 433-439.

Borsani, O.; Valpuesta, V.; Botella, M.

2001 Evidence for a Role of Salicylic Acid in the Oxidative Damage Generated by $\mathrm{NaCl}$ and Osmotic Stress in Arabidopsis Seedlings. Plant Physiology 126: 1024-1030.

Cardona, C.; Sánchez, O.; Ramírez, J.; Alzate, L.

2004 Biodegradación de residuos orgánicos de plazas de mercado. Revista Colombiana de Biotecnología 6: 78-89.

Chinnusami, V.; Jagendorf, A.; Zhu, J.

2005 Understanding and improving salt tolerance in plants. Crop Science 45: 437-448
FAO

1995 Biotecnología apropiable: racionalidad de su desarrollo y aplicación en América Latina y el Caribe. J. Izquierdo; L. Ciampi; E. de García (eds). Santiago, Chile. 81 pp. García, P.

2007 Uredinales en plantas silvestres y cultivadas del valle de Azapa. Memoria para título de Ing. Agrónomo. Universidad de Tarapacá. Facultad de Ciencias Agronómicas, Carrera de Agronomía. Chile. 98 pp.

Gunes, A.; Inal, A.; Alpaslan, M.; Cicek, N.; Guneri, E.; Eraslan, F.; Guzelordu, T.

2005 Effects of exogenously applied salicylic acid on the induction of multiple stress tolerance and mineral nutrition in maize (Zea mays L.). Archives of Agronomy and Soil Science 51: 687-695.

Gunes, A.; Inal, A.; Alpaslan, M.; Eraslan, F.; Guneri, E.; Cicek, N. 2007 Salicylic acid changes on some physiological parameters symptomatic for oxidative stress and mineral nutrition in maize (Zea mays L.) grown under salinity. Journal of Plant Physiology 164: 728-736. 
Hernández, J.A.; Almanza, M.S.

2002 Short-term effects of salt stress on antioxidant systems and leaf water relations of pea leaves. Physiologia Plantarum 115: 251-257.

Hernández, J.A.; Ferrer, M.A.; Jiménez, A.; Ros-Barceló, A.; Sevilla, F.

2001 Antioxidant systems and $\mathrm{O}_{2}-/ \mathrm{H}_{2} \mathrm{O}_{2}$ production in the apoplast of Pisum sativum L. leaves: its relation with $\mathrm{NaCl}-$ induced necrotic lesions in minor veins. Plant Physiology 127: 817-834.

Horie, T.; Schroeder, J.

2004 Sodium transporters in plants. Diverse genes and physiological functions. Plant Physiology 136: 2457-2462.

Maggio, A.; De Pascale, S.; Angelino, G.; Ruggiero, C.; Barbieri, G. 2004 Physiological response of tomato to saline irrigation in long-term salinized soils. European Journal of Agronomy 21: 149-159.

Mansour, M.M.F.; Van Hasselt, P.R.; Kuiper, P.J.C. $2000 \mathrm{NaCl}$ effects on root plasma membrane ATPase of salt tolerant wheat. Biología Plantarum 43: 61-66.

Martínez-Ballesta, M.d.C.; Bastías, E.; Zhu, C.; Schäffner,

A.R.; González-Moro, B.; González-Murúa, C.; Carvajal, M.

2008 Boric acid and salinity effects on maize roots. Response of aquaporins ZmPIP1 and ZmPIP2, and plasma membrane H+-ATPase, in relation to water and nutrient uptake. Physiologia Plantarum 132: 479-490.

Munns, R.; Husian, S.H.; Rivelli, R.; James, R.; Condon, A.G.; Lindsay, M.; Lagudah, E.S.; Schachtman, D.P.; Hare, R.A.

2002 Avenues for increasing salt tolerance of crops, and the role of physiologically based selection traits. Plant and Soil 247: 93-105.
Olmedilla, A.; Alche J., Rodríguez

2012 Identificación histológica y ultraestructural de plantas C4 y CAM in. "C4 y CAM. Características Generales y Uso: En Programas de Desarrollo de Tierras Áridas y Semiáridas”. Gonzales J. and Chueca A. 107-114.

Omoto, E.; Taniguchi, M.; Miyake, H.

2012 Adaptation responses in C4 photosynthesis of maize under salinity. Journal of Plant Physiology 169: 469-477.

Parida, A.K.; Mitra, B.; Das, A.B.; Das, T.K.; Mohanty, P. 2004 High salinity reduces the content of a highly abundant 23-kDa protein of the mangrove Bruguiera parviflora. Planta 221: 135-140.

Rahman, M.S.; Matsumuro, T.; Miyake, H.; Takeoka, Y. 2000 Salinity induced ultrastructural alterations in leaf cells of rice (Oryza sativa L.). Plant Production Science 3: 422-429.

Rao, M.V.; Davis, K.R.

1999 Ozone-induced cell death occurs via two distinct mechanisms. The role of salicylic acid. Plant Journal 17: 603-614.

Romero-Aranda, R.; Soria, T.; Cuartero, J.

2001 Tomato plant-water uptake and plant-water relationships under saline growth conditions. Plant Science 160: 265-272.

Yamane, K.; Mitsuya, S.H.; Kawasaki, M.; Taniguchi, M.; Miyake, $\mathrm{H}$.

2004 Salinity-induced chloroplast damages in rice leaves (Oryza sativa L.) are reduced by pretreatment with methyl viologen. Proceeding, 4th International Crop Science Congress, Brisbane (Australia), 7 pp. 
